\title{
Regionale arbeidsmarktprognoses 2013-2018, methodiek en resultaten
}

Citation for published version (APA):

Clerx, R., Cörvers, F., \& Fouarge, D. (2014). Regionale arbeidsmarktprognoses 2013-2018, methodiek en resultaten. ROA. ROA Technical Reports No. 002 https://doi.org/10.26481/umarot.2014002

Document status and date:

Published: 01/01/2014

DOI:

10.26481/umarot.2014002

Document Version:

Publisher's PDF, also known as Version of record

\section{Please check the document version of this publication:}

- A submitted manuscript is the version of the article upon submission and before peer-review. There can be important differences between the submitted version and the official published version of record.

People interested in the research are advised to contact the author for the final version of the publication, or visit the DOI to the publisher's website.

- The final author version and the galley proof are versions of the publication after peer review.

- The final published version features the final layout of the paper including the volume, issue and page numbers.

Link to publication

\footnotetext{
General rights rights.

- You may freely distribute the URL identifying the publication in the public portal. please follow below link for the End User Agreement:

www.umlib.nl/taverne-license

Take down policy

If you believe that this document breaches copyright please contact us at:

repository@maastrichtuniversity.nl

providing details and we will investigate your claim.
}

Copyright and moral rights for the publications made accessible in the public portal are retained by the authors and/or other copyright owners and it is a condition of accessing publications that users recognise and abide by the legal requirements associated with these

- Users may download and print one copy of any publication from the public portal for the purpose of private study or research.

- You may not further distribute the material or use it for any profit-making activity or commercial gain

If the publication is distributed under the terms of Article $25 \mathrm{fa}$ of the Dutch Copyright Act, indicated by the "Taverne" license above, 
Maastricht University

Research Centre for Education and the Labour Market | ROA

\section{Regionale arbeidsmarktprognoses 2013-2018, methodiek en resultaten}

Rick Clerx

Frank Cörvers

Didier Fouarge

\section{ROA Technical Report}

ROA-TR-2014/2

Research Centre for Education and the Labour Market Maastricht University

P.O. Box 616, 6200 MD Maastricht, The Netherlands

$\mathrm{T}+31433883647 \mathrm{~F}+31433884914$

secretary-roa-sbe@maastrichtuniversity.n www.roa.nl 


\title{
Regionale arbeidsmarktprognoses 2013-2018, methodiek en resultaten
}

\author{
Rick Clerx \\ Frank Cörvers \\ Didier Fouarge
}

ROA-TR-2014/2

februari 2014

Research Centre for Education and the Labour Market Maastricht University

P.O. Box 616, 6200 MD Maastricht, The Netherlands $\mathrm{T}+31433883647 \mathrm{~F}+31433884914$

secretary-roa-sbe@maastrichtuniversity.nl www.roa.nl 


\section{Inhoud}

Voorwoord 4

1 Inleiding 5

2 Uitgangspunten regionalisering $\quad 6$

3 Hoofdlijnen van het regionale prognosemodel $\quad 8$

3.1 ITA als discrepantie-indicator $\quad 8$

3.2 Componenten van arbeidsvraag en -aanbod 11

$\begin{array}{ll}3.3 \text { Pendel als aanpassingsproces } & 14\end{array}$

4 'Between' en 'within' effecten bij de uitbreidingsvraag naar opleiding 22

5 Arbeidsmarktprognoses tot 2018 naar regio 28

6 Conclusies 37

$\begin{array}{ll}\text { Literatuur } & 39\end{array}$ 


\section{Voorwoord}

Dit werkdocument geeft de methodiek weer die gevolgd is bij het vertalen van de landelijke arbeidsmarktprognoses van het ROA naar 35 regio's. De landelijke arbeidsmarktprognoses zijn in december 2013 gepubliceerd in het rapport De arbeidsmarkt naar opleiding en beroep tot 2018. Het rapport biedt een overzicht van recente trends op de Nederlandse arbeidsmarkt, alsook van de huidige en te verwachten toekomstige ontwikkelingen in de periode 2013-2018. In het landelijke rapport ontbreekt de vertaalslag van de arbeidsmarktprognoses naar de regio's. De resultaten van deze vertaalslag zijn sinds januari 2014 opgenomen in het Arbeidsmarktinformatiesysteem (AIS) van het ROA. Doordat de groeiperspectieven, de industriële structuur, de vergrijzing van de werkzame beroepsbevolking en het aanbod van gediplomeerden van onderwijsinstellingen van regio's aanzienlijk van elkaar kunnen verschillen, kan het toekomstig arbeidsmarktperspectief van eenzelfde opleiding uiteenlopen in de diverse arbeidsmarktregio's.

De arbeidsmarktinformatie op landelijk en regionaal niveau wordt elke twee jaar samengesteld in het kader van het Project Onderwijs-Arbeidsmarkt (POA). De gegevens zijn van belang voor zowel het geven van voorlichting aan degenen die aan een opleiding willen beginnen als het nemen van beleidsbeslissingen door instanties die betrokken zijn bij de aansluiting tussen het onderwijs en de arbeidsmarkt.

Het POA wordt gefinancierd door het Ministerie van Onderwijs, Cultuur en Wetenschap (OCW), het UWV WERKbedrijf, het Ministerie van Economische Zaken (EZ), het Ministerie van Binnenlandse Zaken en Koninkrijksrelaties (BZK), de stichting Samenwerking Beroepsonderwijs Bedrijfsleven (SBB) en Randstad Nederland. 


\section{$1 \quad$ Inleiding}

In dit werkdocument wordt ingegaan op de prognosemethodiek en de belangrijkste bevindingen van de regionale arbeidsmarktperspectieven tot 2018 voor afgestudeerden van mbo, hbo en wo. De gebruikte bronnen, begrippen en methodiek sluiten zoveel als mogelijk aan bij het rapport De arbeidsmarkt naar opleiding en beroep tot 2018 (ROA, 2013). In het rapport wordt reeds ingegaan op het doel van de arbeidsmarktprognoses, en een beknopte weergave van de gehanteerde methodiek met een beschrijving van de centrale begrippen gegeven. De uitgangspunten van het Project Onderwijs-Arbeidsmarkt en de prognosemethodiek zijn uitgebreider uiteengezet in verschillende andere publicaties. Zie daarvoor tevens de referenties bij de centrale begrippen in Bijlage A van De arbeidsmarkt naar opleiding en beroep tot 2018 (ROA, 2013).

Het doel van het Project Onderwijs-Arbeidsmarkt (POA) is om inzicht te verschaffen in de actuele en de op middellange termijn verwachte situatie op de arbeidsmarkt, verbijzonderd naar beroep en opleiding. De regionale arbeidsmarktprognoses naar opleiding dienen vooral ter ondersteuning van beslissingen over de macrodoelmatigheid van opleidingen. Beter inzicht in de toekomstige situatie op de regionale arbeidsmarkt kan helpen om het aanbod van voorzieningen bij verschillende onderwijsinstellingen beter op elkaar en op de arbeidsvraag van werkgevers af te stemmen. Ook kan deze informatie worden gebruikt als signaal bij de studie- en beroepskeuze van jongeren, eventueel in combinatie met de meer gedetailleerde landelijke arbeidsmarktprognoses naar opleidingstype. De publicatie van de regionale arbeidsmarktprognoses is erop gericht om voortijdig discrepanties tussen vraag een aanbod op regionaal niveau te kunnen vaststellen. Door het afgeven van 'early warnings' aan provincies, gemeentes, UWV WERKbedrijf, uitzend- en bemiddelingsbureaus, werkgeversorganisaties en niet te vergeten onderwijsinstellingen kunnen beleidsmakers maatregelen nemen en individuele actoren (studiekiezers, werkzoekenden, werkgevers) hun beslissingen aanpassen. 
De regionalisering van de landelijke arbeidsmarktprognoses sluit aan bij de behoefte van gebruikers van deze informatie. Daarbij wordt door beleidsmakers aangegeven dat de regionalisering omwille van de bruikbaarheid betrekking moet hebben op een indeling naar 35 arbeidsmarktregio's, zoals deze door de VNG, SZW, UWV en SBB is overeengekomen. Gezien de beperkte steekproefomvang van de Enquête Beroepsbevolking (EBB) van het Centraal Bureau voor de Statistiek (CBS) is er voor gekozen de regionale differentiatie van de landelijke ROA-prognoses naar opleiding te beperken tot 5 opleidingscategorieën op mboniveau, 6 opleidingscategorieën op hbo-niveau en het totaal van het wo. Het gaat hierbij om een doorvertaling van de landelijke prognoses naar de 35 arbeidsmarktregio's, waarbij rekening is gehouden met de vraag- en aanbodontwikkelingen over de volledige breedte van de arbeidsmarkt.

Dit werkdocument is als volgt opgebouwd. In paragraaf 2 wordt een aantal uitgangspunten van de regionalisering besproken. Vervolgens wordt in paragraaf 3 ingegaan op de prognosemethodiek. In paragraaf 4 wordt de uitbreidingsvraag naar opleiding nader toegelicht. De kernbevindingen worden in paragraaf 5 besproken. Paragraaf 6 wordt afgesloten met enkele aandachtspunten voor vervolgonderzoek.

\section{Uitgangspunten regionalisering}

In deze paragraaf worden de uitgangspunten van de regionalisering van de arbeidsmarktprognoses toegelicht. In de onderstaande tabel is getracht de uitgangspunten op een overzichtelijke wijze samen te vatten. Het gaat hier met name om de keuze voor een 'top-down' in plaats van een 'bottom-up' benadering, zowel wat betreft de methodiek als de gebruikte databronnen (zie Cörvers, 2003). Dat impliceert dat landelijke uitkomsten worden geregionaliseerd op basis van verdeelmodellen en landelijke data worden uitgesplitst naar regio, onder meer om consistentie tussen de regionalisering en de landelijke ontwikkelingen te waarborgen. Er wordt voorbij gegaan aan informatie en databronnen die alleen 
voor bepaalde regio's in een specifieke vorm beschikbaar zijn, bijvoorbeeld eigenstandige, lokale monitoring van werkgelegenheid en schoolverlaters.

Wel is er bij de modellering bijzondere aandacht voor de geografische mobiliteit in de vorm van verhuizingen en pendel. Het verhuisgedrag van afgestudeerden wordt betrokken bij de verdeling van de arbeidsmarktinstroom van schoolverlaters naar regio en opleidingscategorie. De pendel is van belang om anpassingsprocessen expliciet te modelleren bij de interactie tussen vraag en aanbod op de verschillende regionale arbeidsmarkten. Hiervoor worden pendelgegevens naar opleiding gebruikt. Deze gegevens over gediplomeerden van het mbo, hbo en wo zijn nog niet zo lang integraal beschikbaar door de koppeling die bij het CBS is gemaakt tussen DUO-gegevens en de UWV-polisadministratie van werkenden.

\section{Tabel 1}

Uitgangspunten bij de methodiek van de regionalisering van de landelijke arbeidsmarktprognoses

\begin{tabular}{|l|l|}
\hline $\begin{array}{l}\text { Uitgangspunt bij } \\
\text { regionalisering }\end{array}$ & Toelichting \\
\hline $\begin{array}{l}\text { Doorvertaling landelijke } \\
\text { prognoses met één } \\
\text { verdeelmodel voor alle } \\
\text { regio's }\end{array}$ & $\begin{array}{l}\text { Consistentie, robuustheid en referentiekader voor gebruikers: } \\
\text { voor alle regio's dezelfde uitgangspunten ten aanzien van de } \\
\text { modellering en de verwachte landelijke } \\
\text { arbeidsmarktontwikkelingen tot 2018 (zie ROA, 2013). }\end{array}$ \\
\hline $\begin{array}{l}\text { Landelijke databronnen die } \\
\text { worden gebruikt }\end{array}$ & $\begin{array}{l}\text { Bij de doorvertaling is er voor gekozen landelijke databronnen } \\
\text { van het CBS en sectorprognoses van het EIM te gebruiken. Het } \\
\text { gaat om: } \\
-\end{array}$ \\
$\begin{array}{l}\text { Enquête Beroepsbevolking (EBB) van het CBS voor } \\
\text { beroepsbevolking naar sector, opleiding, leeftijdsklasse en } \\
\text { geslacht; } \\
\text { Sociaal Statistisch Bestand (SSB) van het CBS, waarin de } \\
\text { koppeling tussen gediplomeerden (DUO) en werkenden } \\
\text { (polisadministratie) tot stand wordt gebracht, voor gegevens } \\
\text { over pendel naar opleiding; } \\
\text { Sectorprognoses naar regio van het EIM op basis van het } \\
\text { PRISMA-R model, waarin de landelijke sectorprognoses } \\
\text { worden geregionaliseerd (zie Kwaak, 2006). }\end{array}$ \\
\hline
\end{tabular}




\begin{tabular}{|c|c|}
\hline 35 arbeidsmarktregio's & $\begin{array}{l}\text { Sterke voorkeur van beleidsmakers (VNG, SBB, UWV, SZW), } \\
\text { vergaande uitsplitsing met name gewenst op middelbaar } \\
\text { beroepsniveau. }\end{array}$ \\
\hline 22 bedrijfssectoren & $\begin{array}{l}\text { Sluit aan bij de landelijke ROA-prognoses en de sectorindeling } \\
\text { van EIM en UWV. }\end{array}$ \\
\hline $\begin{array}{l}12 \text { opleidings-categorieën } \\
\text { mbo, hbo en wo }\end{array}$ & $\begin{array}{l}\text { Informatie dient vooral ter ondersteuning van het regionale beleid } \\
\text { voor verbetering van de macrodoelmatigheid van opleidingen, en } \\
\text { bij de studie- en beroepskeuzevoorlichting aan jongeren. Een } \\
\text { uitsplitsing naar bijna } 90 \text { mbo-, hbo- en wo- opleidingstypen zou } \\
\text { te zeer ten koste gaan van de betrouwbaarheid van de regionale } \\
\text { prognoses. }\end{array}$ \\
\hline $\begin{array}{l}\text { Vraag en aanbod op de } \\
\text { arbeidsmarkt zijn } \\
\text { gerelateerd aan woonregio }\end{array}$ & $\begin{array}{l}\text { Er moet een keuze worden gemaakt tussen woon- of werkregio } \\
\text { om vraag en aanbod te confronteren. De keuze voor woonregio is } \\
\text { gebaseerd op: } \\
\text { - } \quad \text { Er zijn meer arbeidsmarktgegevens beschikbaar naar } \\
\text { woonregio dan naar werkregio; } \\
\text { - Werkregio is niet altijd goed vast te stellen, bijv. voor } \\
\text { werkzoekenden, maar ook een voor deel van de werkenden. }\end{array}$ \\
\hline $\begin{array}{l}\text { Aanpassingsprocessen } \\
\text { hebben betrekking op } \\
\text { regionale mobiliteit }\end{array}$ & $\begin{array}{l}\text { Deze zijn bij kleine regio's vooral voor hoger opgeleiden van } \\
\text { belang. Er wordt rekening gehouden met: } \\
\text { - } \quad \text { verhuizing van jongeren na afstuderen; } \\
\text { - } \quad \text { pendel van werkende afgestudeerden tussen regio's . }\end{array}$ \\
\hline
\end{tabular}

\section{Hoofdlijnen van het regionale prognosemodel}

\subsection{ITA als discrepantie-indicator}

Op regionaal niveau wordt gebruik gemaakt van eenzelfde discrepantie-indicator als bij de landelijke arbeidsmarktprognoses. Dat betekent dat de regionale ITA voor de 35 regio's vergeleken mag worden met de landelijke ITA. Voor de 12 opleidingscategorieën van mbo, hbo en wo worden de verwachte regionale vraag naar nieuwkomers en het verwachte regionale aanbod aan elkaar gerelateerd. Vraag en aanbod op de regionale arbeidsmarkt worden in beginsel vastgesteld aan de hand 
van verdeelmodellen, welke in deze en de volgende subparagraaf nader worden toegelicht.

$\mathrm{Er}$ is overeenkomstig de landelijke arbeidsmarktprognoses gekozen voor een tijdshorizon van de prognoses tot en met 2018 met als basisjaar 2012. Deze termijn houdt rekening met een studieduur van veel jongeren van 4 tot 5 jaar. Dit voorkomt een procyclisch beleid, dat te sterk reageert op de actuele arbeidsmarktsituatie. De perspectieven voor schoolverlaters op de regionale arbeidsmarkt worden weergegeven in de Indicator Toekomstige Arbeidsmarktperspectief (ITA). Deze indicator voor de toekomstige discrepantie tussen het verwachte aanbod en de verwachte vraag op de arbeidsmarkt wordt per opleidingscategorie en regio bepaald volgens formule (1):

$$
I T A=\frac{(100+\text { instroom } \%+\text { kortdurig werklozen } \%)}{(100+\max \{0, \text { uitbreidingsvraag } \%\}+\text { vervangingsvraag } \%+\text { substitutievraag } \%)}(1)
$$

Het verwachte aanbod tot 2018 per opleiding en regio bestaat uit de verwachte instroom vanuit het onderwijs en de kortdurig werklozen. De verwachte vraag is gelijk aan het aantal baanopeningen dat in de prognoseperiode ontstaat als gevolg van de (positieve) uitbreidingsvraag, de vervangingsvraag en de substitutievraag. Voor zover nieuwkomers op de arbeidsmarkt hinder ondervinden van een krimpende werkgelegenheid, wordt dit met de vervangingsvraag verrekend.

Naarmate de waarde van de ITA hoger ligt, is er sprake van een slechter arbeidsmarktperspectief voor schoolverlaters. Anders gezegd, de inspanning die zij moeten leveren om een baan te kunnen bemachtigen is groter naarmate de ITA hoger is. Een waarde van iets groter dan 1 duidt op een redelijk evenwichtige situatie. Een lagere score voor de ITA impliceert een beter arbeidsmarktperspectief voor schoolverlaters. Conform de landelijke methodiek wordt de regionale ITA naar boven afgerond op twee decimalen, en uitgedrukt in vijf kwalitatieve typeringen voor het arbeidsmarktperspectief van schoolverlaters: slecht, matig, redelijk, goed en zeer goed. Hoe beter het arbeidsmarktperspectief van 
schoolverlaters is, hoe groter over het algemeen de knelpunten in de personeelsvoorziening van werkgevers voor de betreffende opleidingen.

Als het toekomstige aanbod van schoolverlaters en kortdurig werklozen volgens de ITA niet toereikend is om de verwachte vraag te vervullen, zullen werkgevers op zoek moeten naar andere oplossingen om hun knelpunten in de personeelsvoorziening op te lossen. Dit gaat doorgaans met aanpassingskosten gepaard. ${ }^{1}$ Voor de hand liggende maatregelen zijn bijvoorbeeld het verbeteren van de arbeidsvoorwaarden (hogere loonkosten), maar ook het intensiveren van de wervingsinspanningen. Dit laatste kan tevens betekenen dat er in een groter gebied geworven moet worden, dat wil zeggen in andere regio's of zelfs internationaal. Andere aanpassingsprocessen zijn het anders inrichten van het productieproces, met een aangepaste taakverdeling van het beschikbare personeel, het zelf opleiden van vakkrachten uit het eigen personeelsbestand, of het trainen van nieuw personeel met een iets afwijkende achtergrond qua opleiding en ervaring. Werkgevers kunnen bovendien het arbeidspotentieel aanboren van langdurig werklozen, arbeidsgehandicapten en potentiële herintreders. Deze laatste groepen komen vaak pas in beeld als de knelpunten in de personeelsvoorziening voor bepaalde opleidingen hoog oplopen omdat er te weinig direct inzetbaar aanbod van schoolverlaters en kortdurig werklozen is, en als zij enige opleiding en ervaring in de veel gevraagde richtingen hebben.

1. Zie Borghans en Willems (1998) voor de interpretatie van (verwachte) discrepanties ('gaps') tussen vraag en aanbod op de arbeidsmarkt. Deze moeten niet letterlijk als tekorten en overschotten van personen worden geïnterpreteerd, maar geven de grootte van de spanning (fricties) naar opleiding (en regio) weer. 


\subsection{Componenten van arbeidsvraag en -aanbod}

In het rapport De arbeidsmarkt naar opleiding en beroep tot 2018 (ROA, 2013) en het bijbehorende methodiekrapport wordt uitgebreid ingegaan op de methodiek van de verschillende componenten van vraag en aanbod. Dit zijn de uitbreidings-, vervangings- en substitutievraag, en de instroom van schoolverlaters en de kortdurige werkloosheid an de aanbodzijde van de arbeidsmarkt. De veronderstellingen voor de periode tot 2018 ten aanzien van de macroeconomische ontwikkeling en de landelijke werkgelegenheidsprognoses naar sector worden hier eveneens toegelicht. Voorts wordt er ingegaan op de verschillende indicatoren voor de discrepantie tussen vraag en aanbod, en op de substitutieprocessen op de arbeidsmarkt.

Zoals in paragraaf 3.1 al genoemd, zijn de regionale werkgelegenheidsprognoses naar sector van het EIM gebruikt als input voor de regionale uitbreidingsvraag naar opleiding. Ook deze prognoses zijn gebaseerd op een verdeelmodel van het EIM (Kwaak, 2006) en consistent met de landelijke werkgelegenheidsprognoses naar sector van het ROA, welke eveneens door het EIM worden opgesteld. De regionale werkgelegenheidsprognoses naar sector zijn te gebruiken om de invloed van intersectorale verschuivingen van de regionale werkgelegenheid op de regionale uitbreidingsvraag naar opleiding te bepalen. Dit is het zogenaamde 'between effect' van de sectorale werkgelegenheids-verschuivingen op de uitbreidingsvraag naar opleiding, waarop dieper wordt ingegaan in paragraaf 4. Daar wordt ook duidelijk gemaakt dat intrasectorale werkgelegenheidsverschuivingen, het zogenaamde 'within effect' waaronder ook de 'upgradingstrend' valt, veel moeilijker vast te stellen en te voorspellen zijn. In de landelijke prognoses wordt voor de upgradingstrend teruggegrepen op het model dat is ontwikkeld door Dupuy (2006). Het verschil tussen de landelijke uitbreidingsvraag voor een opleidingscategorie en de optelsom van de uitbreidingsvraag over alle regio's wordt toegeschreven aan het 'within effect' voor de regio's, en wordt herverdeeld over alle regio's. 
Er zijn twee belangrijke veronderstellingen bij de regionale uitbreidingsvraag naar opleiding. Ten eerste wordt er voor de berekening van het 'between effect' eenzelfde landelijke matrix van de werkgelegenheid van sector naar opleiding gebruikt voor alle arbeidsmarktregio's. Er zou bij vervolgonderzoek moeten worden nagegaan in hoeverre de veronderstelling klopt dat regio's vooral verschillen in sectorstructuur, maar veel minder in de opleidingssamenstelling binnen dezelfde sectoren (idem voor beroepen). Ten tweede wordt verondersteld dat de verandering van de opleidingssamenstelling over de tijd van dezelfde sectoren binnen verschillende regio's eenzelfde trend van upgrading volgen.

De vervangingsvraag wordt alleen beïnvloed door de uitstroom van werkenden voor zover dit tot nieuwe vraag leidt. De landelijke vervangingsvraag houdt rekening met uittrede door pensionering of in verband met de zorg voor gezinsleden, en met de doorstroom op de arbeidsmarkt als men ander werk gaat doen (andere beroepsgroep of met hoger opleidingsniveau). In de landelijke prognoses van de vervangingsvraag wordt bovendien rekening gehouden met de stijging van de participatiegraad. De landelijke vervangingsvraag naar opleiding wordt verdeeld naar de grootte van de werkzame beroepsbevolking per regio. Er wordt rekening gehouden met de verschillen in samenstelling naar leeftijdklasse en geslacht tussen de arbeidsmarktregio's, waarbij wordt verondersteld dat deze verschillen zich bij alle opleidingen op gelijke wijze manifesteren.

Uitgangspunt is de landelijke vervangingsvraag naar 102 verschillende opleidingstypen. Voor elk opleidingstype is de vervangingsvraag berekend op basis van de zogenaamde cohort-componenten methode (Willems en De Grip, 1993). Hierbij worden uitstroomcoëfficiënten per cohort geschat. De totale verwachte vervangingsvraag in de prognoseperiode (incl. alle correcties) wordt voor elk opleidingstype toegerekend aan de 20 cohorten (i.e. 10 leeftijdsklassen van vijf jaar per geslacht). 
Vervolgens wordt er rekening gehouden met de mate waarin de regionale verdeling van de werkzame beroepsbevolking naar leeftijd en geslacht afwijkt van de landelijke verdeling. Er wordt verondersteld dat de regionale afwijking voor elk opleidingtype in een regio dezelfde is.

Samengevat wordt de landelijke vervangingsvraag per opleidingstype onderverdeeld naar cohorten, en wordt per opleidingstype de vervangingsvraag van een cohort vermenigvuldigd met de verhouding tussen het regionale en het landelijke werkgelegenheidsaandeel van een cohort, en het aandeel van de werkzame beroepsbevolking van een arbeidsmarktregio in het landelijke totaal. Per arbeidsmarktregio ontstaat er op deze wijze een vervangingsvraag voor 102 opleidingstypen, uitgesplitst naar cohorten van leeftijd en geslacht. Tot slot wordt de vervangingsvraag geaggregeerd naar de 12 opleidingscategorieën op mbo-, hboen wo-niveau.

Naast het totaal aantal baanopeningen uit hoofde van uitbreidings- en vervangingsvraag wordt aan de vraagkant rekening gehouden met de landelijke substitutievraag. Deze volgt uit de confrontatie tussen vraag en aanbod op landelijk niveau. De substitutievraag wordt verdeeld op basis van de verdeling van de werkzame beroepsbevolking over regio's.

Het aanbod op de arbeidsmarkt bestaat uit de som van de verwachte arbeidsmarktinstroom van schoolverlaters in de prognoseperiode en het aantal kortdurig werklozen aan het begin van de prognoseperiode (personen die korter dan één jaar werkloos zijn). Deze laatste groep is op te vatten als het boven de markt zwevende aanbod van werklozen. Het regionale aanbod van werklozen wordt verdeeld op basis van het aandeel werklozen van een regio in het landelijke totaal, waarbij wordt rekening met de verschillen per opleidingstype.

De landelijke arbeidsmarktinstroom van schoolverlaters wordt verdeeld naar rato van het aantal werkzame jongeren (tot 30 jaar oud) over de verschillende 
woonregio's. Derhalve wordt daarbij rekening gehouden met verhuizingen van afgestudeerden naar andere regio's dan hun woonregio. Er wordt verondersteld dat het verhuisgedrag van schoolverlaters in beginsel onveranderd blijft, en dat aanpassingen in de traditionele verhuisdynamiek na afstuderen gepaard gaat met fricties en aanpassingskosten.

\subsection{Pendel als aanpassingsproces}

Veranderingen in pendelstromen kunnen worden beschouwd als een aanpassingsproces dat in gang wordt gezet als de verschillende arbeidsmarktregio's van elkaar afwijken wat betreft aantrekkingskracht op een opleiding. De arbeidsmarktregio's zijn immers geen op zichzelf staande 'eilandjes'. Sommige regio's hebben veel interactie met andere regio's, in termen van inkomende en uitgaande pendel, andere regio's veel minder. Hoewel veranderingen in pendelstromen aanpassingskosten met zich mee brengen, wordt verondersteld dat deze relatief klein zijn ten opzichte van eventuele verhuizingen. Aanpassingen in pendelstromen leiden ertoe dat regionale arbeidsmarkten meer met elkaar in evenwicht worden gebracht. Daar waar de pendelstromen tussen regio's al groot zijn, is er wellicht slechts een kleine verandering van de pendelstromen nodig om een meer evenwichtige situatie op de verschillende regionale arbeidsmarkten te bewerkstelligen.

Bij de modellering van de aanpassing van de pendelstroom wordt uitgegaan van de woonregio van de beroepsbevolking. Een belangrijk voordeel daarvan is dat het arbeidsaanbod (incl. werklozen) eenvoudig kan worden gerelateerd an de woonregio. Aan de andere kant is de arbeidsvraag veel gemakkelijker te relateren aan de werkgelegenheid en dus de werkregio van personen. Er is niettemin gekozen voor woonregio als uitgangspunt voor de regionale arbeidsmarktprognoses omdat het onbenutte arbeidspotentieel moeilijk aan een werkregio kan worden toegewezen. Bovendien is de werkregio van een substantieel deel van de werkenden niet bekend. De woonregio is daarentegen bijna altijd wel bekend. Een ander voordeel van de keuze voor de woonregio is dat deze aansluit bij de veronderstelling dat werkzoekenden (met of zonder baan) vaak als eerste kijken naar de 14 
werkgelegenheid in de eigen (woon)regio voordat men buiten de eigen regio een baan zoekt.

Als men moet pendelen of verhuizen naar een andere regio kan dat gepaard gaan met aanzienlijke aanpassingskosten, die doorgaans toenemen bij grotere afstanden. De ITA drukt de frictie op een regionale arbeidsmarkt uit, en geeft een indicatie van de hoogte van de aanpassingskosten die daaruit voortkomen. De veronderstelling is dat afgestudeerden in eerste instantie werk binnen de eigen regio proberen te vinden, of naar regio's vertrekken waar eerdere cohorten van afgestudeerden ook terecht kwamen. Dit laatste wordt verondersteld bekend te zijn voor de meeste afgestudeerden bij aanvang van de studie, waardoor de aanpassingskosten relatief klein zijn ten opzichte van de situatie dat men onverwachts en met weerzin moet verhuizen naar een andere regio om een baan te bemachtigen. Als er afgeweken moet worden van het reguliere historische, verhuisgedrag van grote groepen afgestudeerden, dan leidt dit waarschijnlijk tot grotere aanpassingskosten. Ook pendel naar een andere regio dan de woonregio leidt vanzelfsprekend tot aanpassingskosten, vooral als het gaat om verder weg gelegen regio's.

De inkomende pendelstroom kan stijgen als gevolg van een slechtere arbeidsmarktsituatie in een andere regio (y) dan de woonregio ( $\mathrm{x}$, waarbij ITAy>ITAx). Er ontstaat dan concurrerend aanbod voor de beroepsbevolking van regio $\mathrm{x}$. Door de additionele arbeidsmarktinstroom stijgt de ITA in de woonregio $\mathrm{x}$ (ITAx), hetgeen betekent dat het toekomstig arbeidsmarktperspectief van de beroepsbevolking in regio $\mathrm{x}$ verslechtert. Van belang is hier dat de beroepsbevolking van regio $\mathrm{x}$ 'last heeft' van de verwachte arbeidsmarktontwikkeling in regio y. Andersom verbetert het arbeidsmarktperspectief van de beroepsbevolking in regio y in de gedachtegang van het model niet direct door de verwachte toename van de uitgaande pendel van y naar $\mathrm{x}$, omdat deze toename van de uitgaande pendel juist als een manifestatie moet worden gezien van de hogere ITA (i.e. slechtere arbeidsmarktsituatie) in regio 
$\mathrm{y}$ ten opzichte van regio $\mathrm{x}$. Het aanpassingsproces voor regio y wordt gemodelleerd via de inkomende pendel van regio $\mathrm{x}$. De inkomende pendel uit regio x neemt af, waardoor de toekomstige arbeidsmarktsituatie in regio y iets verbetert.

De arbeidsmarktinstroom voor een willekeurige opleidingscategorie in woonregio $\mathrm{x}$ is als volgt gedefinieerd:

$$
I N x=I N x, x+I N x, y
$$

waarbij

$I N x=$ instroom van schoolverlaters in regio $\mathrm{x}$;

$I N x, x=$ instroom van schoolverlaters die in regio $\mathrm{x}$ wonen en in regio $\mathrm{x}$ werken;

$I N x, y=$ instroom van schoolverlaters die in regio $\mathrm{x}$ wonen en in regio $\mathrm{y}$ werken, dat wil zeggen uitgaande pendel.

In het model vindt er een aanpassing plaats van de regionale arbeidsmarktinstroom van schoolverlaters in regio $\mathrm{x}$ aan de hand van de inkomende pendel vanuit andere regio's. Hoe groter deze pendel is, hoe kleiner de 'afstand' van regio y naar regio x. Deze afstand geeft weer hoe aantrekkelijk het voor schoolverlaters van regio y is om in regio $\mathrm{x}$ te werken. De aantrekkingskracht hangt samen met bijvoorbeeld fysieke afstand, reistijd en reiscomfort, maar ook met de aantrekkelijkheid van de werkomgeving. De anpassing van de instroom is een functie van regionale verschillen in arbeidsmarktperspectieven (ITA's) en de 'afstand'. De verandering van de arbeidsmarktinstroom in regio $\mathrm{x}$ ten gevolge van een aanpassing in de inkomende pendel wordt weergegeven door:

$$
\begin{aligned}
& I N x^{\prime}=I N x+I N y, x *\left((I T A x-I T A y+1)^{2}-1\right) \text { indien ITA } \geq I T A y \\
& I N x^{\prime}=I N x+I N y, x *\left(-1 *(I T A x-I T A y-1)^{2}-1\right) \text { indien ITA }<<\text { ITAy }
\end{aligned}
$$

waarbij tevens 
$I N x^{\prime}=$ aangepaste instroom van regio $\mathrm{x}$;

$I N y, x=$ instroom van mensen die in regio $\mathrm{y}$ wonen en in regio $\mathrm{x}$ werken oftewel inkomende pendel;

IT Ax - IT Ay $=$ het verschil in ITA tussen regio $\mathrm{x}$ en y voor een bepaalde opleidingscategorie. ${ }^{2}$

Het verschil in ITA tussen regio $\mathrm{x}$ en $\mathrm{y}$ wordt gekwadrateerd, zodanig dat de arbeidsmarktinstroom in regio x groter (c.q. kleiner) wordt als de ITA in regio y groter (c.q. kleiner) is dan in regio $\mathrm{x}$, dat wil zeggen dat de arbeidsmarktsituatie voor schoolverlaters in regio y slechter (c.q. beter) is dan in regio x. Daardoor gaat het toekomstig arbeidsmarktperspectief van schoolverlaters in regio $\mathrm{x}$ meer lijken op die in regio y.

De verandering van de pendel is evenredig met het verschil in ITA's in het kwadraat om de volgende reden. In de migratieliteratuur is geografische mobiliteit vaak afhankelijk van de afstand tussen regio's en de aantrekkelijkheid van zowel herkomst- als bestemmingsregio (Poot, Waldorf, Van Wissen, 2008). De verandering van de pendel ( $\mathrm{INx}^{\prime}$ - INx) wordt derhalve in het gebruikte regionale model afhankelijk gesteld van het product van de afstand (benaderd door de bestaande inkomende pendel $\mathrm{INy}, \mathrm{x}$ ) en de relatieve aantrekkelijkheid van regio y (ITAy-ITAx) als herkomstregio van de inkomende pendel en regio x (ITAx-ITAy) als bestemmingsregio. Hierdoor ontstaat er een kwadratisch verband tussen aanpassingen van de pendelstroom en het verschil in ITA's tussen twee regio's. Het verschil in ITA's heeft daardoor een meer dan evenredige invloed op de aanpassing in de pendelstroom en daarmee de toe- of afname van de arbeidsmarktinstroom in regio $x$.

2 Indien ITAx $\geq$ ITAy, dan $\left((I T A x-I T A y+1)^{2}-1\right) \geq 0$; indien ITAx<ITAy, dan $\left(-1 *(\text { IT Ax }- \text { ITAy }-1)^{2}-1\right)<0$. 
De aangepaste arbeidsmarktinstroom (INx') wordt vervolgens gebruikt voor de berekening van een nieuwe ITAx' volgens vergelijking (1). Daardoor gaan kort bij elkaar gelegen regio's (i.e. regio's met veel onderlinge pendel) meer op elkaar lijken wat betreft het arbeidsmarktperspectief van schoolverlaters met dezelfde opleidingsachtergrond. Dat is precies wat er wordt beoogd met het modelleren van het aanpassingsproces. Door de aanpassingen van de ITA's worden grote verschillen in arbeidsmarktperspectief van gelijke opleidingen tussen nabij gelegen regio's in meer of mindere mate 'glad gestreken'. Dit geeft naar verwachting een reëler beeld van het toekomstig arbeidsmarktperspectief van de betreffende opleidingscategorieën in de 35 onderscheiden arbeidsmarktregio's.

De regionale aanpassingsprocessen voltrekken zich in de bovenstaande vergelijking volledig langs de aanbodzijde van de arbeidsmarkt. Hoewel de verdeling van de arbeidsmarktinstroom naar regio's reeds anticipeert op verhuizingen van jongeren naar andere regio's dan de afstudeerregio's, dient er ook te worden gekeken naar de pendelstromen tussen regio's. Uitgangspunt is dat de confrontatie tussen arbeidsvraag en -aanbod per woonregio gebeurt. Dat wil zeggen dat de vraag naar personen in een woonregio niet per se hoeft te komen van de bedrijven die in dezelfde woonregio gevestigd zijn. Het gaat dus in eerste instantie om de vraag naar personen die tot de beroepsbevolking van de betreffende woonregio behoren. Dit geldt voor de uitbreidingsvraag, de substitutievraag en de vervangingsvraag. Daarnaast zijn ook de personen in de beroepsbevolking van de betreffende regio (i.e. het arbeidsaanbod van de regio) niet per se werkzaam in de woonregio, maar kunnen zij pendelen voor werk naar andere regio's (de werkregio). De beroepsbevolking van een regio is derhalve potentieel aanbod voor de eigen regio en alle andere regio's.

De confrontatie tussen vraag naar de beroepsbevolking en aanbod van de beroepsbevolking in een regio kan derhalve betrekking hebben op vraag en aanbod in zowel de eigen (woon)regio als in andere regio's. Een uitsplitsing hiervan wordt in de regionale arbeidsmarktprognoses niet gedaan. Een grote vraag naar personen 
uit regio $\mathrm{x}$ vanuit werkregio $\mathrm{y}$ (uitbreidings- en/of vervangingsvraag) kan bijvoorbeeld aansluiten bij een grote arbeidsmarktinstroom in woonregio x. Het perspectief voor deze personen in woonregio $\mathrm{x}$ is dan toch goed omdat de vraag in werkregio y zo groot is. Het is echter niet direct zichtbaar dat deze vraag door werkgevers in regio y wordt uitgeoefend, omdat de arbeidsvraag is weergegeven in de vraag naar personen die behoren tot de beroepsbevolking van regio x. De pendelstroom van regio $\mathrm{x}$ naar $\mathrm{y}$ is hierbij impliciet, en wordt niet gemodelleerd.

Bij de berekening van de ITAx en ITAy gaat het dus om de arbeidsmarktperspectieven van personen die woonachtig zijn in regio $x$ respectievelijk regio y, waarbij men over en weer kan pendelen voor werk in de andere regio. Zolang de ITA's in alle regio's hetzelfde zijn zullen de bestaande pendelstromen niet veranderen. De regionale ITA's hebben dan uiteraard geen toegevoegde waarde ten opzichte van de landelijke ITA. Veranderingen in het pendelgedrag kunnen wel worden verwacht als de regionale ITA's wel afwijken van elkaar en van de landelijke ITA.

Als de ITA voor een opleidingscategorie in een angrenzende regio hoger (dus slechter voor schoolverlaters) is dan in de woonregio $\mathrm{x}$ dan zal er naar verwachting additioneel aanbod zijn vanuit regio $\mathrm{y}$ naar regio $\mathrm{x}$, waardoor de ITA dient te worden herberekend. Dat additionele aanbod wordt berekend door het kwadratisch verschil in ITA's tussen regio's te vermenigvuldigen met de bestaande pendel van regio $\mathrm{y}$ naar $\mathrm{x}$ (inkomende pendel) voor de betreffende opleidingscategorie.

De aangepaste instroom voor regio $\mathrm{x}$ wordt meegenomen in de herziene berekening van de ITA. Zoals eerder gesteld is de bestaande pendel feitelijk een soort afstandsmaat tussen regio's. Als er veel inkomende pendel vanuit regio y naar $\mathrm{x}$, duidt dat op een kleine (relatieve) afstand tussen y en x. Daarbij is het ook mogelijk dat bijvoorbeeld regio $\mathrm{x}$ meer een woonfunctie heeft (met zogenaamde forensengemeentes) en regio y meer een werkgelegenheidsfunctie (met bijvoorbeeld 
veel bedrijventerreinen). Indien de pendel van y naar $\mathrm{x}$ zeer groot is, kan men zich zelfs afvragen of de regio's y en $\mathrm{x}$ wel aparte regio's zijn. De aanpassing van de ITA aan de hand van de inkomende pendel kan worden beschouwd als een zogenaamde passief aanpassingsproces, dat wil zeggen de pendelstroom van een andere regio reageert op verschillen in de arbeidsmarktsituatie tussen regio's.

Omgekeerd kan de ITA van een opleidingscategorie in regio y ook lager zijn dan in regio $x$. Dat betekent dat het verwachte arbeidsmarktperspectief van deze opleidingscategorie in regio y beter is dan in regio $\mathrm{x}$. In dat geval mag verwacht worden dat de inkomende pendel in regio x vanuit regio y zal afnemen. De daaruit volgende afname van het arbeidsaanbod is afhankelijk van de grootte van de bestaande inkomende pendel en van het kwadratische verschil tussen de ITA's van regio $\mathrm{x}$ en $\mathrm{y}$.

Achter de genoemde aanpassing van de pendelstromen ligt een aantal veronderstellingen ten grondslag. Zo wordt aangenomen dat het aanpassingsmechanisme zich voltrekt via de aanpassing van de inkomende pendel. De uitgaande pendel wordt hierbij niet opgenomen in het aanpassingsmechanisme. Dit hangt samen met de idee dat in de berekening van de ITA van een woonregio alleen op aanpassingen in de pendelstromen moet worden geanticipeerd voor zover deze pendel van andere regio's afkomstig is. Een afname of toename van de uitgaande pendel van regio $\mathrm{x}$ door een slechtere c.q. betere arbeidsmarktsituatie in regio $\mathrm{x}$ ten opzichte van $\mathrm{y}$, is namelijk te beschouwen als een manifestatie van de frictie of mismatch in regio $\mathrm{x}$ (ten opzichte van regio $\mathrm{y}$ ) waarmee beroepsbevolking van regio $\mathrm{x}$ geconfronteerd wordt.

Ten gevolge van het verschil in ITA's tussen regio $\mathrm{x}$ en $\mathrm{y}$ kan het arbeidsaanbod in meer of mindere mate terecht in de eigen woonregio voor een baan. De hogere 
(lagere) aanpassingskosten die ontstaan als men meer (minder) gaat pendelen naar een andere regio is precies wat de ITA wil weergeven, waardoor het niet gewenst is deze verschuiving in het regionale arbeidsaanbod te in de ITA op te nemen. ${ }^{3}$ Een tweede reden is dat de uitgaande pendel (INx,y) al in de arbeidsmarktstroom van regio $\mathrm{x}(\mathrm{INx})$ is inbegrepen (waarbij $\mathrm{INx}=\mathrm{INx}, \mathrm{x}+\mathrm{INx}, \mathrm{y}$ ), omdat de keuze is gemaakt vraag en aanbod te confronteren per woonregio, ongeacht degenen die buiten de woonregio werken en de arbeidsvraag naar de beroepsbevolking van de woonregio door werkgevers in andere regio's.

Een andere veronderstelling is dat de historische inkomende pendel als afstandsmaat tussen regio's wordt beschouwd. Deze wordt bovendien verondersteld lineair samen te hangen met de grootte van de aanpassing van de arbeidsmarktinstroom, en met het kwadratische verschil tussen de ITA's van de verschillende regio's. Tot slot wordt ook verondersteld dat het arbeidsaanbod reageert op de vraag van bedrijven en instellingen, en niet andersom. Voor de middellange termijn waarop de prognoses betrekking hebben, lijkt dat de meest voor de hand liggende veronderstelling.

3. Dit onderscheid naar inkomende en uitgaande pendel lijkt qua gedachtegang op het verschil tussen de zogenaamde passieve en actieve substitutieprocessen tussen opleidingen. In het landelijke model wordt ernaar gestreefd wel passieve maar geen actieve substitutie mee te nemen in de berekening van de ITA. Actieve substitutie is bijvoorbeeld het uitwijken van opleidingen met een slechte arbeidsmarktpositie naar opleidingen met een initieel betere arbeidsmarktpositie. De uitwijk als zodanig is een manifestatie van een slechte arbeidsmarktpositie, en hoeft niet te worden gemodelleerd. Niettemin verslechtert daardoor ook de positie van andere opleidingen ('olievlekwerking'), en dat dient wel te worden gemodelleerd. Zie Borghans en Heijke (1996) en Cörvers en Heijke (2004). 


\section{4 'Between' en 'within' effecten bij de uitbreidingsvraag naar opleiding}

In deze paragraaf wordt de methode voor de berekening van de absolute verandering van de werkgelegenheid per opleidingscategorie en regio nader besproken. De methode is afgeleid van de 'shift-share analyse', zoals deze wordt toegepast in Esteban (2000) en Cörvers en Meriküll (2007). Shift-share analyses worden gebruikt om regionale verschillen in opleidingsstructuur te ontleden in 'between' (tussen) sector- en 'within' (binnen) sectoreffecten. Het totale effect van de verandering van het absoluut aantal werkenden met opleiding $i$ in regio $r$ is de optelsom van de verandering in elke sector $s$ in de regio:

$$
\Delta W_{i, r}=\sum_{s} \Delta W_{i, s, r}
$$

Hierin staat W staat voor de werkgelegenheid van opleiding i, sector s, regio $r$. Het 'between effect' bestaat uit de verandering van de opleidingsstructuur als gevolg van de verandering in de allocatie van de werkgelegenheid tussen sectoren. Het 'within effect' bestaat uit de verandering in de opleidingsstructuur als gevolg van de verandering in de werkgelegenheidssamenstelling van opleidingen binnen sectoren. Deze beide effecten worden gebruikt om de verandering in de werkgelegenheid voor opleidingen te prognosticeren. Het gaat in de volgende vergelijking om de verandering van het absoluut aantal werkenden met opleiding $\mathrm{i}$ in regio $\mathrm{r}$ :

$$
\Delta W_{i, r}=\sum_{s} \Delta W_{s, r} * \frac{W_{i, s, r}}{W_{s, r}}+\sum_{s} \Delta\left(\frac{W_{i, s, r}}{W_{s, r}}\right) * W_{s, r}
$$

De eerste term aan de rechterkant van de vergelijking slaat op het 'between effect', de tweede op het 'within effect'. 
$\mathrm{CPB}$ en EIM stellen landelijke en regionale sectorprognoses van de werkgelegenheid samen (zie verder ROA, 2013). Voor het aandeel van opleidingen in een bepaalde sector ontbreken tot op heden prognoses. ${ }^{4}$ Hierdoor kan er op regionaal niveau alleen gebruik worden gemaakt van het 'between effect', dat wil zeggen de eerste term aan de rechterkant van vergelijking (5):

$$
\Delta W_{i, r}=\sum_{s} \Delta W_{s, r} *\left(\frac{W_{i, s, r}}{W_{s, r}}\right)
$$

Voor de verschillende sectoren wordt aangenomen dat in een bepaald jaar het aandeel van een opleiding in een bepaalde sector voor iedere regio hetzelfde is. Deze aanname gaat ervan uit dat in Nederland de stand van de technologische ontwikkeling en de gebruikte productietechnieken voor een bepaalde sector gelijk zijn in alle regio's. Alle regio's gebruiken dan ongeveer dezelfde kennis over productieprocessen en technologieën.

De aandelen van een opleiding in een bepaalde sector wordt voor iedere regio gelijkgesteld aan de aandelen van deze sector voor Nederland als totaal (landelijk niveau, NL). De volgende vergelijking wordt gebruikt om de verandering in de werkgelegenheid voor opleidingen te prognosticeren:

$$
\Delta W_{i, r}=\sum_{s} \Delta W_{s, r} *\left(\frac{W_{i, s L}}{W_{s, N L}}\right)
$$

4. Het ROA gebruikt op landelijk niveau wel een model om de verandering ('upgradingstrend') van opleidingen binnen beroepen te berekenen. Zie Dupuy (2006) en ROA (2005, paragraaf 1.7) over onder meer 'skill-biased technological change'. Uiteraard kan ook 'job polarization' een rol spelen bij de verandering in de aandelen van opleidingen binnen sectoren, waarbij de werkgelegenheid aan de boven- en onderkant van de arbeidsmarkt groeit dan wel min of meer in stand blijft, maar waarbij vooral de werkgelegenheid op middelbaar beroepsniveau terugloopt. 
In tabel 2 zijn bij wijze van voorbeeld aantallen werkenden te vinden voor twee opleidingen binnen drie sectoren. Voor de prognoses van de uitbreidingsvraag naar opleiding zijn alleen prognoses van de werkgelegenheid naar sector beschikbaar (de EIM-prognoses). Daarom wordt aan de hand van de aantallen werkenden in tabel 2 een voorbeeldprognose besproken waarbij alleen het 'between effect' waarneembaar is, i.e. de sectoren groeien of krimpen maar de verhouding van de opleidingen binnen de sectoren blijft gelijk.

\section{Tabel 2}

Numeriek voorbeeld met uitsluitend 'between' effecten voor de werkgelegenheid van sectoren en opleidingen, aantal werkenden in jaar $t$ en jaar $t+1$

jaar $t$

\begin{tabular}{|c|c|c|c|c|}
\hline & & ople & & \\
\hline & & 1 & 2 & totaal \\
\hline & 1 & 10 & 12 & 22 \\
\hline$\tilde{\sigma}$ & 2 & 8 & 6 & 14 \\
\hline 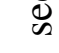 & 3 & 14 & 7 & 21 \\
\hline & Totaal & 32 & 25 & \\
\hline
\end{tabular}

jaar $t+1$

\begin{tabular}{|c|c|c|c|c|}
\hline \multicolumn{5}{|c|}{ opleiding $i$} \\
\hline \multirow{5}{*}{ 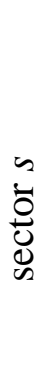 } & & 1 & 2 & totaal \\
\hline & 1 & 15 & 18 & 33 \\
\hline & 2 & 4 & 3 & 7 \\
\hline & 3 & 14 & 7 & 21 \\
\hline & totaal & 33 & 28 & \\
\hline
\end{tabular}

In het voorbeeld van tabel 2 treden er geen veranderingen van de aandelen van de opleidingen binnen sectoren op. Deze aandelen zijn constant tussen jaar $t$ en jaar $t+1$. De voorbeeldcijfers van tabel 2 worden ingevuld in vergelijking (7). Dit levert voor opleiding 1 de volgende prognose van de verandering van de werkgelegenheid in deze regio op:

$$
\begin{aligned}
& \Delta W_{1, r}=(33-22) * \frac{10}{22}+(7-14) * \frac{8}{14}+(21-21) * \frac{14}{21} \\
& \Delta W_{1, r}=11 * \frac{10}{22}+(-7) * \frac{8}{14}+0 * \frac{14}{21} \\
& \Delta W_{1, r}=\frac{110}{22}-\frac{56}{14}+\frac{0}{21}=1
\end{aligned}
$$

Voor opleiding 2 geeft dit de volgende prognose van de verandering van de werkgelegenheid in deze regio: 


$$
\begin{aligned}
& \Delta W_{2, r}=(33-22) * \frac{12}{22}+(7-14) * \frac{6}{14}+(21-21) * \frac{7}{21} \\
& \Delta W_{2, r}=11 * \frac{12}{22}+(-7) * \frac{6}{14}+0 * \frac{7}{21} \\
& \Delta W_{2, r}=\frac{132}{22}-\frac{42}{14}+\frac{0}{21}=3
\end{aligned}
$$

Voor beide opleidingen is te zien dat de veranderingen in de werkgelegenheid, als benadering voor de uitbreidingsvraag naar opleiding, goed worden voorspeld. Hieruit kan worden geconcludeerd dat de prognose de veranderingen van de werkgelegenheid voor opleidingen goed voorspelt in het geval van 'between' zonder 'within' effecten.

Om te illustreren hoe de werkgelegenheidsprognose kan uitpakken wanneer er naast between ook within effecten zijn, worden de aantallen werkenden van tabel 3 gebruikt. In deze voorbeeldtabel groeien en krimpen er sectoren, en vinden daarnaast verschuivingen plaats in de verhouding van opleidingen binnen de sectoren, i.e. er zijn between én within effecten.

\section{Tabel 3}

Numeriek voorbeeld met 'between' en 'within' effect voor de werkgelegenheid van sectoren

\begin{tabular}{|c|c|c|c|c|}
\hline & & opl & & \\
\hline & & 1 & 2 & totaal \\
\hline & 1 & 10 & 12 & 22 \\
\hline $\bar{\sigma}$ & 2 & 8 & 6 & 14 \\
\hline $\mathscr{\infty}$ & 3 & 14 & 7 & 21 \\
\hline & totaal & 32 & 25 & \\
\hline
\end{tabular}
en opleidingen, aantal werkenden in jaar $t$ en jaar $t+1$

jaar $t$

\begin{tabular}{|c|c|c|c|c|}
\hline & & ople & & \\
\hline & & 1 & 2 & totaal \\
\hline & 1 & 10 & 15 & 25 \\
\hline$\overline{0}$ & 2 & 4 & 6 & 10 \\
\hline$\Phi$ & 3 & 14 & 7 & 21 \\
\hline & Totaal & 28 & 28 & \\
\hline
\end{tabular}

jaar $t+1$ 
In eerste instantie worden hier de aandelen van opleidingen in een sector van jaar t+1 niet gebruikt bij de werkgelegenheidsprognose, om het verschil met de werkelijke ontwikkeling te illustreren. Er wordt dus weer gebruik gemaakt van vergelijking (7), dat wil zeggen zonder rekening te houden met within effecten. Dit levert voor opleiding 1 de volgende prognose van de verandering van de werkgelegenheid in deze regio op:

$$
\begin{aligned}
& \Delta W_{1, r}=(25-22) * \frac{10}{22}+(10-14) * \frac{8}{14}+(21-21) * \frac{14}{21} \\
& \Delta W_{1, r}=3 * \frac{10}{22}+(-4) * \frac{8}{14}+0 * \frac{14}{21} \\
& \Delta W_{1, r}=\frac{30}{22}-\frac{32}{14}+\frac{0}{21}=-0.922 \neq-4
\end{aligned}
$$

Voor opleiding 2 geeft dit de volgende prognose van de verandering van de werkgelegenheid in deze regio:

$$
\begin{aligned}
& \Delta W_{2, r}=(25-22) * \frac{12}{22}+(10-14) * \frac{6}{14}+(21-21) * \frac{7}{21} \\
& \Delta W_{2, r}=3 * \frac{12}{22}+(-4) * \frac{6}{14}+0 * \frac{7}{21} \\
& \Delta W_{2, r}=\frac{36}{22}-\frac{24}{14}+\frac{0}{21}=-0.078 \neq 3
\end{aligned}
$$

Uit de berekening met de aantallen werkzame personen uit tabel 3 kan worden afgeleid dat de prognosemethode op basis van 'between' effecten niet goed werkt wanneer er ook 'within' effecten optreden. In het regionale prognosemodel van het ROA zijn de within effecten helaas niet op een vergelijkbare manier te berekenen als de between effecten omdat er geen betrouwbare prognoses voorhanden zijn van de verschuivingen van opleidingsaandelen binnen sectoren. Daarom zijn de landelijke verschuivingen van opleidingen binnen sectoren (de landelijke 'upgradingstrend') als benadering genomen voor de within effecten in de regio's. Met de landelijke upgradingstrend wordt bedoeld een prognose die de within effecten voorspelt, i.e. die de verandering van de verhouding tussen de opleidingen binnen een bepaalde sector weergeeft. 
Op basis van tabel 3 kan ter illustratie ook het within effect op regionaal niveau worden berekend, aan de hand van de tweede term aan de rechterkant van vergelijking (5). De landelijke upgrading wordt derhalve als volgt berekend:

$$
\text { landelijke upgrading }=\sum_{s} \Delta\left(\frac{W_{i, s, N L}}{W_{s, N L}}\right) * W_{s, r}
$$

Zonder upgrading, dus met de between effecten maar zonder de within effecten, is de volgende prognose gemaakt van aantallen werkenden in jaar $t+1$ in tabel 3:

$$
\begin{aligned}
& \Delta W_{1, r}=\frac{30}{22}-\frac{32}{14}+\frac{0}{21}=-0.922 \\
& \Delta W_{2, r}=\frac{36}{22}-\frac{24}{14}+\frac{0}{21}=-0.078
\end{aligned}
$$

Vervolgens wordt de landelijke upgradingstrend toegepast om de within effecten te meten. Het within effect voor opleiding 1 is:

$$
\begin{aligned}
& \text { landelijke upgrading }=\sum_{S} \Delta\left(\frac{W_{1, s, N L}}{W_{S, N L}}\right) * W_{s, r} \\
& \text { landelijke upgrading }=\left(\frac{10}{25}-\frac{10}{22}\right) * 22+\left(\frac{4}{10}-\frac{8}{14}\right) * 14+\left(\frac{14}{21}-\frac{14}{21}\right) * 21 \\
& \text { landelijke upgrading }=-\frac{30}{550} * 22-\frac{34}{140} * 14+0 * 21 \\
& \text { landelijke upgrading }=-3.6
\end{aligned}
$$

Het within effect voor opleiding 2 is:

$$
\text { landelijke upgrading }=\sum_{S} \Delta\left(\frac{W_{2, s, N L}}{W_{S, N L}}\right) * W_{s, r}
$$




$$
\begin{aligned}
& \text { landelijke upgrading }=\left(\frac{15}{25}-\frac{12}{22}\right) * 22+\left(\frac{6}{10}-\frac{6}{14}\right) * 14+\left(\frac{7}{21}-\frac{7}{21}\right) * 21 \\
& \text { landelijke upgrading }=\frac{30}{550} * 22+\frac{34}{140} * 14+0 * 21 \\
& \text { landelijke upgrading }=3.6
\end{aligned}
$$

Om de totale verandering van de werkgelegenheid naar opleiding te prognosticeren zullen de between en within effecten bij elkaar moeten worden opgeteld:

$$
\begin{aligned}
& \Delta W_{1, r}=-0.922-3.6=-4.522 \approx-4 \\
& \Delta W_{2, r}=-0.078+3.6=3.522 \approx 3
\end{aligned}
$$

Er blijkt dat er nog steeds een (relatief klein) verschil is tussen de geprognosticeerde veranderingen van de werkgelegenheid en de gerealiseerde veranderingen. Deze verschillen zijn toe te wijzen aan het 'interaction' effect (zie bijv. Cörvers en Meriküll, 2007). Het interaction effect ontstaat als gevolg van de interactie tussen veranderingen van het aandeel van opleidingen binnen sectoren en veranderingen van de werkgelegenheid van sectoren.

\section{Arbeidsmarktprognoses tot 2018 naar regio}

In deze paragraaf worden de uitkomsten van de prognoses naar vraag en aanbod samengevat weergegeven. Het gaat hierbij om de verschillende factoren van vraag en aanbod op de arbeidsmarkt die in de ITA-berekening zijn gebruikt om het arbeidsmarktperspectief te berekenen. Het betreft derhalve de uitbreidings- (UV), vervangings- (VV), substitutievraag (SV), arbeidsmarktinstroom (IN) en kortdurige werkloosheid (KW). Deze zijn voor elke opleidingscategorie uitgedrukt als percentage van werkzame beroepsbevolking in 2012 (het basisjaar van de prognose). Voor elke component is in de onderstaande tabellen het gemiddelde percentage, de standaard deviatie, en het minimum- en maximumpercentage over 
de 35 arbeidsmarktregio's weergegeven. Dit is gedaan voor de opleidingscategorieën in het mbo, het hbo en het wo. ${ }^{5}$ Bovendien is dit ter illustratie apart gedaan voor mbo techniek en hbo economie. Tot slot wordt een indruk gegeven van de omvang van de pendelaanpassingen en de uitkomsten voor de discrepantie-indicator (ITA).

Uit de tabellen blijkt dat de verschillen tussen regio's heel groot kunnen zijn. De belangrijkste componenten zijn de vervangingsvraag (VV) en de arbeidsmarktinstroom (IN). De overige componenten kunnen het verschil maken als vervangingsvraag en instroom niet veel uiteenlopen. De substitutievraag, uitgedrukt als percentage van de werkzame beroepsbevolking, is voor één bepaalde opleidingscategorie hetzelfde in alle regio's.

In het Arbeidsmarktinformatiesysteem (AIS) worden alle resultaten weergegeven voor de 35 regio's, met uitzondering van de opleidingscategorieën van regio's met een te klein aantal werkenden. De resultaten konden hierdoor niet worden weergegeven voor $\mathrm{MBO}$ groen in 5 regio's), $\mathrm{HBO}$ groen (30 regio's) en voor $\mathrm{HBO}$ paramedisch (1 regio). ${ }^{6}$

5. Dat betekent voor de vijf opleidingscategorieën in het mbo, zes opleidingscategorieën in het hbo, en voor wo totaal.

6. Gebaseerd op de richtlijnen van het CBS is als ondergrens 80 observaties genomen. 


\section{Tabel 4}

Vraag en aanbod in 35 arbeidsmarktregio's tot 2018, opleidingscategorieën mbo

\begin{tabular}{|c|c|c|c|c|}
\hline $\begin{array}{l}\% \text { van de } \\
\text { werkgelegenheid in } \\
2012\end{array}$ & Gemiddelde & Std. Dev. & Min. & Max. \\
\hline UV (2013-18) & 0,26 & 2,86 & $-6,32$ & 8,14 \\
\hline VV (2013-18) & 22,68 & 9,19 & 11,24 & 60,00 \\
\hline IN (2013-18) & 26,45 & 8,51 & 7,41 & 59,42 \\
\hline SV (2013-18) & 0,15 & 0,72 & $-0,49$ & 1,38 \\
\hline KW (2011-12) & 3,54 & 1,56 & 0,65 & 8,26 \\
\hline
\end{tabular}

Bron: ROA (AIS)

Tabel 5

Vraag en aanbod in 35 arbeidsmarktregio's tot 2018, mbo techniek

\begin{tabular}{|l|r|r|r|r|}
\hline $\begin{array}{l}\text { \% van de } \\
\text { werkgelegenheid in } \\
2012\end{array}$ & Std. Dev. & Min. \\
\hline UV (2013-18) & 0,60 & 0,60 & $-2,16$ & 6,93 \\
\hline VV (2013-18) & 20,62 & 6,14 & 12,91 & 40,06 \\
\hline IN (2013-18) & 24,51 & 3,81 & 16,36 & 30,62 \\
\hline SV (2013-18) & $-0,39$ & 0 & $-0,39$ & $-0,39$ \\
\hline KW (2011-12) & 3,28 & 1,46 & 1,47 & 7,91 \\
\hline
\end{tabular}

Bron: ROA (AIS) 
Tabel 6

Vraag en aanbod in 35 arbeidsmarktregio's tot 2018, opleidingscategorieën hbo

\begin{tabular}{|c|c|c|c|c|}
\hline $\begin{array}{l}\% \text { van de } \\
\text { werkgelegenheid in } \\
2012\end{array}$ & Gemiddelde & Std. Dev. & Min. & Max. \\
\hline UV (2013-18) & $-0,51$ & 2,34 & $-8,40$ & 0,02 \\
\hline VV (2013-18) & 12,84 & 8,66 & 0,00 & 35,59 \\
\hline IN (2013-18) & 19,35 & 9,45 & 0,00 & 48,74 \\
\hline SV (2013-18) & 0,17 & 0,76 & $-0,35$ & 1,87 \\
\hline KW (2011-12) & 3,21 & 2,36 & 0,00 & 17,26 \\
\hline
\end{tabular}

Bron: ROA (AIS)

Tabel 7

Vraag en aanbod in 35 arbeidsmarktregio's tot 2018, hbo economie

\begin{tabular}{|l|r|r|r|r|}
\hline $\begin{array}{l}\text { \% van de } \\
\text { werkgelegenheid in } \\
2012\end{array}$ & Semiddelde & Min. & Max. \\
\hline UV (2013-18) & $-0,94$ & 1,90 & $-4,20$ \\
\hline VV (2013-18) & 6,81 & 1,47 & 4,09 & 10,26 \\
\hline IN (2013-18) & 24,21 & 4,44 & 15,78 \\
\hline SV (2013-18) & $-0,35$ & 0 & $-0,35$ & 36,54 \\
\hline KW (2011-12) & 2,99 & 0,82 & 1,67 & $-0,35$ \\
\hline
\end{tabular}

Bron: ROA (AIS) 


\section{Tabel 8}

Vraag en aanbod in 35 arbeidsmarktregio's tot 2018, opleidingscategorieën wo

\begin{tabular}{|c|c|c|c|c|}
\hline $\begin{array}{l}\% \text { van de } \\
\text { werkgelegenheid in } \\
2012\end{array}$ & Gemiddelde & Std. Dev. & Min. & Max. \\
\hline UV (2013-18) & $-0,98$ & 2,09 & $-4,42$ & 6,48 \\
\hline VV (2013-18) & 19,81 & 8,26 & 6,42 & 35,87 \\
\hline IN (2013-18) & 22,81 & 7,95 & 8,07 & 40,62 \\
\hline SV (2013-18) & 0,17 & 0,06 & 0,08 & 0,31 \\
\hline KW (2011-12) & 3,83 & 1,84 & 1,36 & 9,34 \\
\hline
\end{tabular}

Bron: ROA (AIS)

Op basis van de componenten van vraag en aanbod is per opleidingscategorie de (pre-)ITA berekend. Vervolgens is de ITA opnieuw berekend aan de hand van de verwachte aanpassingen in de pendelstromen. Zoals uitgelegd in paragraaf $3.3 \mathrm{kan}$ de inkomende pendel van een bepaalde opleidingscategorie in een regio toe- of afnemen door de interactie met de omliggende regio's. De inkomende pendel in een regio neemt af als de verwachte arbeidsmarktsituatie voor schoolverlaters van de betreffende opleidingscategorie in de omliggende regio's beter is. Daardoor neemt de arbeidsmarktinstroom in de regio ook af $(\Delta N)$, en verbetert vanzelfsprekend het arbeidsmarktperspectief voor schoolverlaters (i.e. de ITA wordt kleiner ten opzichte van de pre-ITA). De grootste afnames zijn weergegeven in tabel 9. In de tabel is te zien dat daardoor het arbeidsmarktperspectief voor een aantal opleidingscategorieën aanzienlijk kan verbeteren. De kwalitatieve typering van de ITA laat echter lang niet altijd een verandering zien, mede door de gehanteerde bandbreedtes voor de ITA.

In tabel 10 zijn de combinaties van opleidingscategorieën en arbeidsmarktregio's weergegeven met de grootste toename van de inkomende pendel en 
arbeidsmarktinstroom. Daardoor verslechtert hier het arbeidsmarktperspectief voor schoolverlaters ten opzichte van de situatie zonder pendelaanpassing. In tabel 9 en 10 komen enkele regio's en opleidingscategorieën vaker voor, zoals Groot Amsterdam, Midden-Utrecht en $\mathrm{HBO}$ groen. Dit is niet toevallig omdat de genoemde regio's grote pendelvolumes hebben. $\mathrm{HBO}$ groen komt vaak voor omdat het een erg kleine opleidingscategorie is, met in veel arbeidsmarktregio's weinig werkenden, waardoor er een relatief grote kans is op uitbijters c.q. onevenwichtigheden in de arbeidsmarktprognoses. De prognoses voor $\mathrm{HBO}$ groen in de tabellen 9 en 10 worden niet weergegeven in het Arbeidsmarktinformatiesysteem (AIS) van het ROA omdat ze onder de gehanteerde ondergrenzen van het aantal werkenden vallen.

\section{Tabel 9}

Aanpassing van de pendel en de instroom in procenten, bij afname van inkomende pendel

\begin{tabular}{|l|l|l|l|l|}
\hline Arbeidsmarktregio & Opleidingscategorie & $\begin{array}{r}\text { Pre- } \\
\text { ITA }\end{array}$ & ITA \\
\hline Groot Amsterdam & WO totaal & slecht & goed & -23.47 \\
\hline Zuid-Holland Centraal & HBO groen & redelijk & goed & -16.82 \\
\hline Midden-Utrecht & WO totaal & slecht & matig & -14.75 \\
\hline Midden-Utrecht & HBO social -cultureel & slecht & slecht \\
\hline
\end{tabular}

Bron: ROA (AIS) 
Tabel 10

Aanpassing van de pendel en de instroom in procenten, bij toename van inkomende pendel

\begin{tabular}{|c|c|c|c|c|}
\hline Arbeidsmarktregio & Opleidingscategorie & $\begin{array}{l}\text { Pre- } \\
\text { ITA }\end{array}$ & ITA & $\Delta \mathrm{IN}$ \\
\hline Groot Amsterdam & MBO sociaal-cultureel & redelijk & matig & 6.97 \\
\hline Groot Amsterdam & $\mathrm{HBO}$ groen & zeer goed & goed & 7.17 \\
\hline Midden-Limburg & $\mathrm{HBO}$ groen & goed & goed & 7.63 \\
\hline Groot Amsterdam & MBO techniek & goed & goed & 7.84 \\
\hline Midden-Utrecht & MBO sociaal-cultureel & matig & matig & 8.47 \\
\hline
\end{tabular}

Bron: ROA (AIS)

Tot slot zijn er voor $\mathrm{MBO}$ groen en $\mathrm{HBO}$ paramedisch twee kaarten opgenomen met daarin de arbeidsmarktperspectieven naar regio. Voor $\mathrm{MBO}$ groen is te zien dat de perspectieven voor schoolverlaters over het algemeen wat minder goed zijn in het Noorden en Oosten van het land. Voor HBO paramedisch zijn de arbeidsmarktperspectieven de laatste jaren verslechterd, o.a. door bezuinigingen. Voor deze opleidingscategorie zijn er arbeidsmarktregio's met zowel goede als slechte arbeidsmarktperspectieven, zelfs als ze in geografische zin niet ver van elkaar gelegen zijn. 
Figuur 1

Indicator toekomstig arbeidsmarktperspectief (ITA) voor afgestudeerden van MBO groen, 20132018

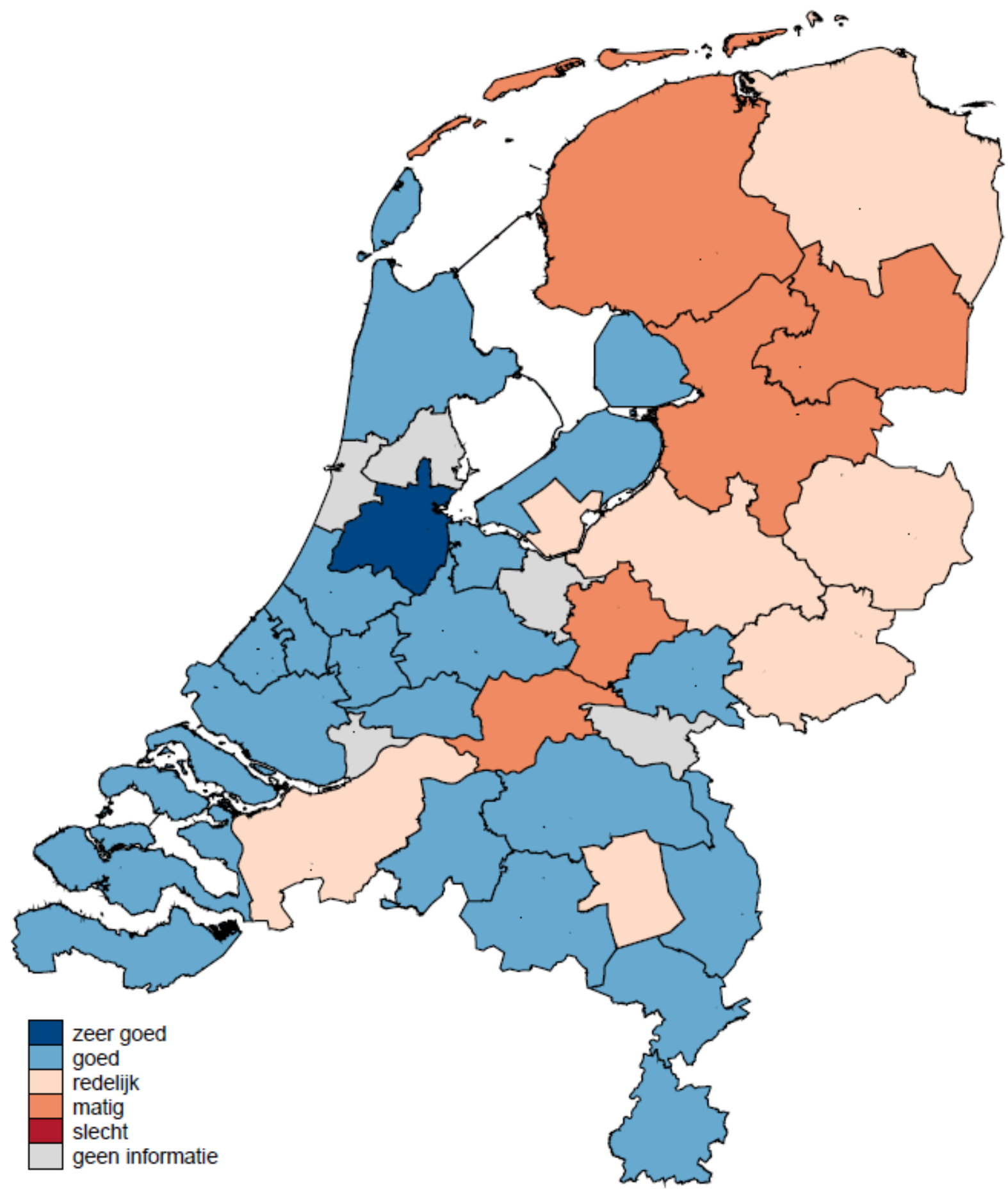

Bron: ROA (AIS) 
Figuur 2

Indicator toekomstig arbeidsmarktperspectief (ITA) voor afgestudeerden van $\mathrm{HBO}$ paramedisch, 2013-2018

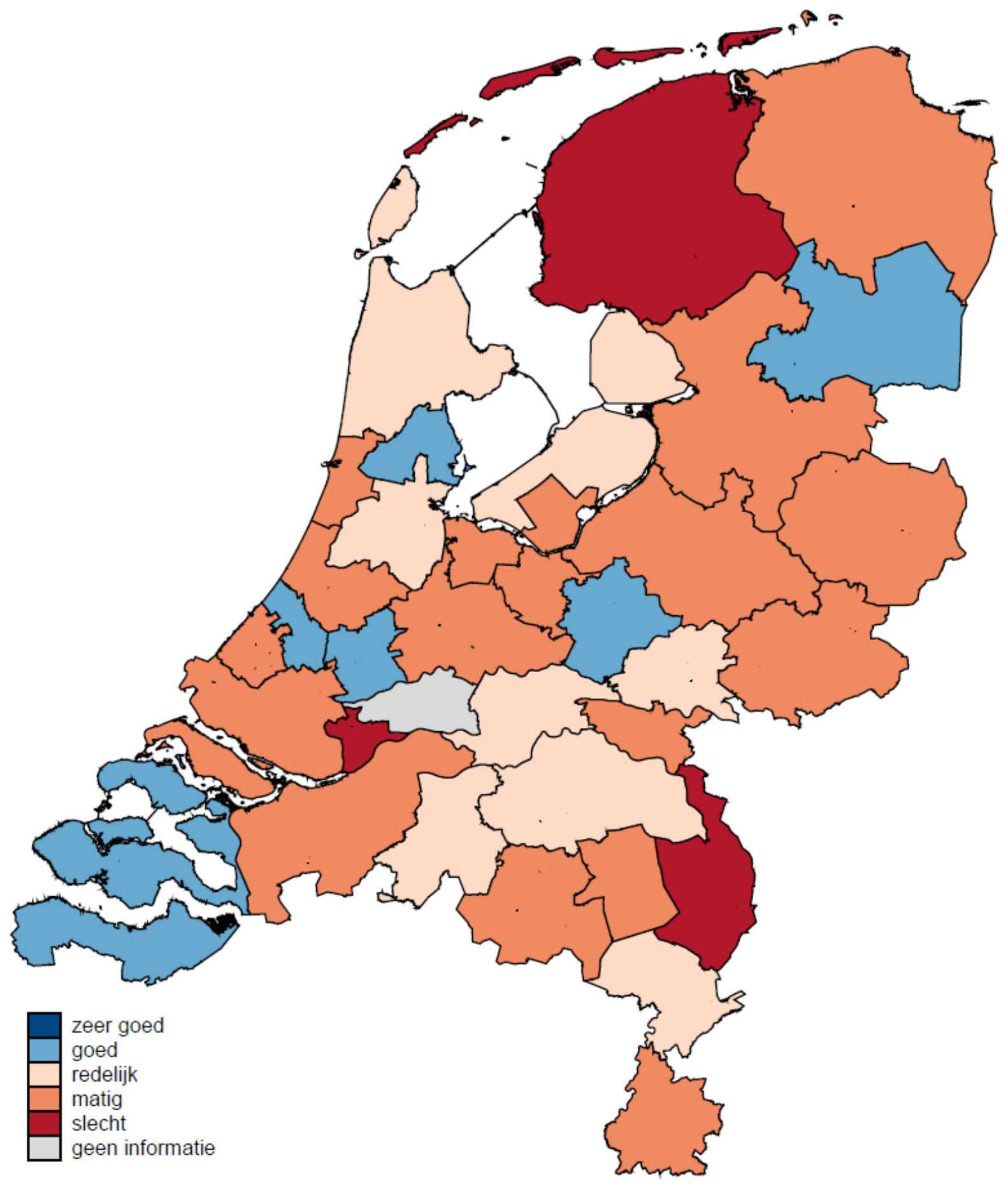

Bron: ROA (AIS) 


\section{Conclusies}

Uit dit werkdocument volgt dat vraag en aanbod op de arbeidsmarkt aanzienlijk kan verschillen tussen regio's. Er is gepoogd om een methodiek te ontwikkelen die aansluit bij het landelijke prognosemodel van het ROA en rekening houdt met de databeperkingen op regionaal niveau. Centraal uitgangspunt is een verdeelmodel voor de componenten van vraag en aanbod. Aanpassingsprocessen zijn gemodelleerd door veranderingen in pendelstromen tussen regio's afhankelijk te stellen van de grootte van de bestaande pendel en het verwachte arbeidsmarktperspectief in de herkomst- en bestemmingsregio's.

De gehanteerde methodiek is voor het eerst gebruikt en kan op een aantal punten wellicht verbeterd worden. Dat betreft met name de punten waar veronderstellingen in het model zijn gemaakt, mede door datarestricties. Het verdient aanbeveling om een aantal veronderstellingen nader te onderzoeken op validiteit en gevolgen voor de uitkomsten, en tevens te kijken waar het model aangevuld kan worden met meer regiospecifieke gegevens, eventueel uit het Sociaal Statistisch Bestand (SSB) van het CBS. Dit geldt in het bijzonder voor de volgende onderdelen:

- Wat betreft de uitbreidingsvraag, hoe belangrijk zijn 'between' ten opzichte van 'within' effecten? Als de matrix sector $\mathrm{x}$ opleiding matrix min of meer gelijk is voor alle regio's, dan zijn 'between' effecten zeer dominant, en verschilt de werkgelegenheid naar opleiding per regio vrijwel alleen door regionale verschillen in industriële (sector)structuur.

- Hetzelfde kan onderzocht worden voor de verandering van de opleidingssamenstelling binnen sectoren over de tijd. Zijn er wat dat betreft verschillen per regio, of is de upgradingssnelheid ongeveer gelijk voor verschillende regio's?

- Er kunnen wellicht meer regiospecifieke elementen worden ingebracht in de vervangingsvraag en de arbeidsmarktinstroom per opleidingscategorie. Er kan hier gedacht worden aan regionale participatiegraden, maar ook aan het gebruik van regionale instroomprognoses op basis van de regionalisering van 
de Referentieramingen die bij het Ministerie van OCW momenteel onderzocht wordt.

- Tot slot is het zinvol om het feitelijke pendelgedrag nader te onderzoeken, omdat het een belangrijke factor is in het huidige regionale prognosemodel. De onderzoeksvraag is in hoeverre pendelstromen zich aanpassen aan de regionale verschillen in de arbeidsmarktsituatie.

Bij het bovenstaande zou er nader empirisch onderzoek moeten plaatsvinden, waarbij voortgebouwd dient te worden op wat uit de wetenschappelijke literatuur reeds bekend is. 


\section{Literatuur}

Borghans, L., H. Heijke (1996), Forecasting the Educational Structure of Occupations: a Manpower Requirement Approach with Substitution, Labour, Vol. 10, pp. 151-192.

Borghans, L., E. Willems (1998), Interpreting Gaps in Manpower Forecasting Models, Labour, Vol. 12, pp. 633-641.

Cörvers, F. (2003), Labour market forecasting in the Netherlands: a top-down approach, in: S.L. Schmidt, K. Schömann, M. Tessaring (eds.), Early identification of skill needs in Europe, Cedefop Reference Series, Vol. 40, Thessaloniki, pp. 72-83.

Cörvers, F., H. Heijke (2004), Forecasting the labour market by occupation and education: Some key issues, ROA-W-2004/4, Maastricht University.

Cörvers, F., J. Meriküll (2007), Occupational structures across 25 EU countries: the importance of industry structure and technology in old and new EU countries, Economic Change and Restructuring, Vol. 40, pp. 327-359.

Dupuy, A. (2006), Measuring Skill-upgrading in the Dutch Labor Market, ROA-W2006/3E, Maastricht University.

Esteban, J. (2000), Regional convergence in Europe and the industry mix: a shiftshare analysis, Regional Science and Urban Economics, Vol. 30, pp. 353-364.

Kwaak, T. (2006), PRISMA-R: modelmatige desaggregatie van bedrijfstakprognoses naar provincie, SCALES-report, H200612, februari, Zoetermeer.

Poot, J., B. Waldorf, L. van Wissen (2008, eds.), Migration and Human Capital, New Horizons in Regional Science, Edward Elgar, Cheltenham, UK, Northampton, MA, USA.

ROA (2005), De arbeidsmarkt naar opleiding en beroep 2010, ROA-R-2005/9, Maastricht University.

ROA (2013), De arbeidsmarkt naar opleiding en beroep 2018, ROA-R-2013/11, Maastricht University.

Willems, E., A. de Grip (1993), Forecasting Replacement Demand by Occupation and Education, International Journal of Forecasting, Vol. 9, pp. 173-185. 